\title{
Interactions of small-scale fisheries in Mexico's northwest Pacific
}

\author{
Francisco Javier Mendoza-Portillo ${ }^{1}$, Mauricio Ramírez-Rodríguez ${ }^{1}$ \& Víctor Vargas-López ${ }^{2}$ \\ ${ }^{1}$ Centro Interdisciplinario de Ciencias Marinas del Instituto Politécnico Nacional (CICIMAP-IPN) \\ La Paz, Baja California Sur, México \\ ${ }^{2}$ Centro Regional de Investigación Acuícola y Pesquera La Paz del Instituto Nacional de Pesca y Acuacultura \\ SAGARPA, La Paz, Baja California Sur, México \\ Corresponding author: Mauricio Ramírez-Rodríguez (mramirr@ipn.mx)
}

\begin{abstract}
In Mexico, as in other parts of the world, there is limited knowledge regarding the operation of small-scale fisheries. Also, there is an urgent need for the diversity of fisheries and their interactions, and the diversity of species to be analyzed on a regional level. In this study, the dynamics of the small-scale fleet operating in San Ignacio in the northwestern Pacific of the state of Baja California Sur were analyzed, recognizing the fishery's multi-species and multi-gear character and its effect on the spatial and temporal distribution of the fishing effort. The operative units (OU) approach was applied; OUs are defined as the set of associated vessels that exploit one or more target species using similar fishing gears. The information about species, gears, sites and fishing seasons was obtained from interviews with 74 fishers. The OUs identified included: diving-pen shell scallop; diving-squalid callista; diving-Pismo clam; collection-black ark; trap-barred sand bass; trap-crab; trap-lobster; cast net-shrimp; bottom net-fish; surface net-fish; bottom net-shark. The variation in the activity of each OU is related to the availability of the resources, prices of the products and official restrictions. From a management perspective, this method helps to clarify which OUs adhere to specific rules associated with their métier and others, which are less well defined since their OU characteristics are associated with their fishery level. The definition and characterization of the OU, based on the local knowledge of the fishermen, assist the design of management schemes that consider the spatial and temporal complexity of the small-scale fisheries.
\end{abstract}

Keywords: fleet dynamic; operative units; artisanal fleets; local knowledge; northwestern Pacific, Mexico

\section{INTRODUCTION}

In Mexico, as in other parts of the world, the artisanal or small-scale fishery (SSF) is characterized by being dynamic and complex involving biological, technical, economic and social variables related to the exploitation of multiple species, gears and fishing methods, coastal environments and local and regional markets (Espino-Barr \& Cruz-Romero, 2006; RamírezRodríguez, 2009; Arreguín-Sánchez \& Arcos-Huitron, 2011; Fernández et al., 2011). These characteristics affect the development of measures for the evaluation and management of the fishery (Berkes et al., 2001; FAO, 2005; Salas et al., 2007; Espinoza-Romero et al., 2014).

In general, the management measures for industrial and small-scale fisheries are related to rules controlling the fishing effort and exploitation rate derived from models of monospecific fisheries. However, this approach is inadequate because of the multi-species nature of the SSF and the presence of biological and technical interactions (Kempf et al., 2016). Besides, on a multi-fleet context, the optimal fishing effort needs to be established by the fleet, taking into account the fact that each fleet may be, harvesting different sets of species and with different exploitation patterns for each of them (ICES, 2008). Thus, for the fisheries that operate in a given region, it is necessary to consider the effect of their spatial-temporal coexistence on the performance of each individual fishery and on the ecosystem (ICES, 2003; Vinther et al., 2004; Branch et al., 2006; Marchal, 2008). The analysis includes fishers' behavior and their relationship with factors such as resources abundance, price of fish products,

Corresponding editor: Patricio Arana 
costs of operation and official fishing restrictions (Rijnsdorp et al., 2000; Salas \& Gaertner, 2004; Tzanatos et al., 2006; Duarte et al., 2009; RamírezRodríguez \& Ojeda-Ruiz, 2012; Barnes-Mauthe et al., 2013). The problem is related with the quantity and quality of data and information about the fisheries that in SSF are generally scarce and difficult to obtain (Marchal et al., 2013), but the analysis of the fleet dynamics can contribute to decision making which affects the fishing performance on a regional level.

The present study intends to characterize the dynamics of the small-scale fishing fleet in a fishing region, i.e., the group of vessels of less than $10 \mathrm{t}$ that operate with an outboard motor in the region of San Ignacio, regardless of the target species. Following ICES (2003), the analysis includes the identification of fisheries and métiers as operative units with different levels of the organization. The fishery is defined as a group of vessels that capture the same target species, utilizing different fishing gears during the same period of the year and within the same area; for example, finfish fisheries (several species) that use gill nets (different models). The métier implicates a homogeneous subdivision of the fishery by vessel-fishing gear type in a given region; for instance, fishing for spiny lobster with traps. The general idea of recognizing operative units is they allow the grouping of trips with landings that are related more precisely to the nature of the fishing activities, and they facilitate the analysis of catch data per unit of effort (ICES, 2003).

Operative units can be identified using official catch landing reports, and data from fishing logbooks or interviews with fishers (Neis et al., 1999; Ulrich et al., 2001; Marchal, 2008; Forcada et al., 2010; Davie \& Lordan, 2011; Castro et al., 2012). The interviews have mainly been used when data are scarce, which is common in many small-scale fisheries (Battaglia et al., 2010; Forcada et al., 2010; Moreno-Báez et al., 2012; González-Álvarez, 2016; Arce-Acosta et al., 2018). In all cases, one issue relates to the geographical scale of the region in which the operative unit is analyzed. For example, regions such as the North Sea (Marchal, 2008), the Portuguese continental shelf (Duarte et al., 2009), the central region of the Mediterranean Sea (Battaglia et al., 2010), the Danish North Sea (Andersen et al., 2012), the non-Iberian European waters (Castro et al., 2012) or the Mozambique Channel (Barnes-Mauthe et al., 2013).

Results can be linked to spatial management measures that recognize regions determined by ecological conditions, types of fleet and the infrastructure of the fishing industry. In each region, there are multiple users, communities and operative units that interact using fishing zones and fishery resources; therefore, in each region, specific management rules could be adapted.

Generally, the spatial references to define fishing regions (effort, catch and operation costs per fishing locality) are obtained from "geographical quadrants" designed based on the knowledge of the spatial distribution of the target resource and the mobility of the fleet. For the small-scale fishery, this is not always possible. For instance, in Mexico, it is common for management methods not to distinguish between fisheries in different regions using appropriate scales (i.e., Mexican Pacific, northern Gulf of California, the western central coast of the Gulf of California) (Moreno-Báez et al., 2010, 2012; Cisneros-Mata et al., 2014; Arce-Acosta et al., 2018). The present study suggests that the characterization of the operative units of small-scale fisheries be the first step in the identification of possible management objectives on a regional fishery level and, therefore, the small-scale fishery in the region of the San Ignacio Lagoon is analyzed as a case study to demonstrate this methodology.

\section{MATERIALS AND METHODS}

\section{Study area}

The San Ignacio Lagoon region is located on the western coast of the Baja California Sur Peninsula, Mexico (Fig. 1), and, concerning fishing resources it extends from Punta Abreojos to the estuary of El Datil, including the San Ignacio Lagoon.

The region is known for its high species diversity of temperate and subtropical origin, and some of these species are of commercial interest (Lluch-Belda, 2000; Funes-Rodríguez et al., 2007). In 1979, it was decreed as a refuge zone for migratory birds, whales and whale calves, and, since 1988, it has been part of the Vizcaino Biosphere Reserve, the largest protected natural area of Mexico.

In the region, there are five coastal communities (Laguna San Ignacio, El Cardón, El Delgadito, El Dátil, and Ejido Luis Echeverría) connected by unpaved roads, and the water, electric energy, education and health services are limited. It is estimated that there are 667 people, of whom 237 make up the economically active population. The primary economic activity is fishing and, to a lesser extent, tourism, associated with the grey whale (Eschrichtius robustus) watching and the aquaculture of oysters Crassostrea gigas and $C$. sikamea (INEGI, 2010; SEMARNAT, 2010).

According to data provided by the National Commission of Aquaculture and Fisheries, the fishing fleet in the San Ignacio region is estimated to be 94 


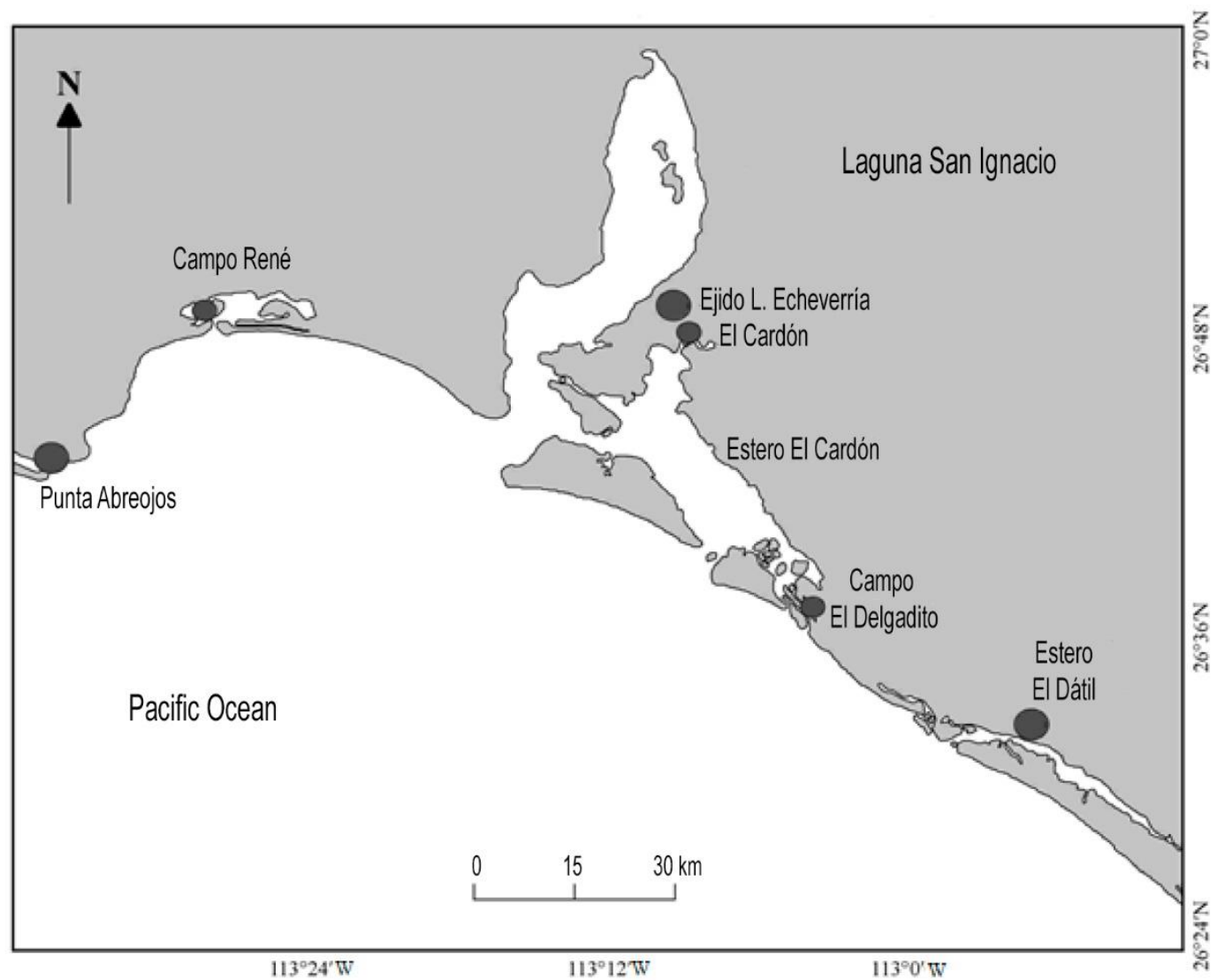

Figure 1. Location of the San Ignacio region on the western coast of Baja California Sur, Mexico.

vessels, each with a capacity of less than $10 \mathrm{t}$ and an outboard motor. Since each vessel holds two fishers, the fleet constitutes approximately 188 fishers, which represents $80 \%$ of the total number of economically active people. Fishing takes place in at least 21 sites located within the lagoon and in the coastal areas that include fishing banks with depths of up to $140 \mathrm{~m}$ (Ramírez-Rodríguez et al., 2010).

The majority of the fishermen are affiliated with the Fisheries Production Cooperatives, and only a few works with private businesses. All the fishermen are covered by licenses for fishing, and some have concessions, both granted by the federal government.

In the region of San Ignacio, there are a history of collapse for abalone, Pismo clam (Tivela stultorum) and Pacific calico scallop Argopecten circularis fisheries (León-Carballo \& Muciño-Díaz, 1996; Massó-Rojas \& Fajardo, 1996). Although there are discussions of the causes, the idea of overexploitation prevails, but the effects of environmental and biological factors associated with the El Niño phenomenon cannot be ruled out. Currently, the total annual catch of different species reaches an average of $1,800 \mathrm{t}$ (Ramírez-Rodríguez et al., 2010). The catch includes fish species of the family Sciaenidae (weakfish) and Pleuronectidae (flounders) (the scientific names can be found in Table 1); in addition, the Mexican spiny lobster Panulirus interruptus, warrior swim crab Callinectes bellicosus, and bivalves of the family Pinnidae (maura pen shell Atrina maura and rugose pen shell Pinna rugose), and Veneridae (Pismo clam Tivela stultorum and squalid callista Megapitaria squalida) have also been recorded. For the shark, ray, lobster and shrimp fishing, management measures have been established that meet Mexican Official Standards (SAGARPA, 2007, 2013, 2016). Moreover, for some species, the National Fisheries Charter provides guidelines for their exploitation (SAGARPA, 2012). The exploitation of the Pismo clam follows the endangered species standards (SEMARNAT, 2010).

\section{Data}

The research strategy is based on the characterization of operative units, considering the spatial and temporal dynamics of each unit and the evaluation of interactions between units. Data were obtained from interviews with 74 fishermen $(40 \%$ of the total fishers in the region) for the purposes of this study. In most cases, the 
Table 1. Exploited species and fishing gears used in the San Ignacio region. Type of fishing gear, 1: diving, 2: manual collection, 3: trap, 4: cast net, 5: bottom net, 6: surface net.

\begin{tabular}{lllc}
\hline Common name & Scientific name & Family & Fishing gear \\
\hline Maura pen shell & Atrina maura & Pinnidae & 1 \\
Rugose pen shell & Pinna rugose & Pinnidae & 1 \\
Pismo clam & Tivela stultorum & Veneridae & 1 \\
Squalid callista & Megapitaria squalida & Veneridae & 1 \\
Black ark & Anadara tuberculosa & Arcidae & 2 \\
Mexican spiny lobster & Panulirus interruptus & Palinuridae & 3 \\
Warrior swim crab & Callinectes bellicosus & Portunidae & 3 \\
Yellowleg shrimp & Farfantepenaeus californiensis & Penaeidae & 4 \\
California flounder & Paralichthys californicus & Paralichthyidae & 5 \\
Barred sand bass & Paralabrax nebulifer & Serranidae & 3 \\
Shortfin weakfish & Cynoscion parvipinnis & Sciaenidae & 6 \\
White weakfish & Atractoscion nobilis & Sciaenidae & 5,6 \\
Yellowtail amberjack & Seriola lalandi & Carangidae & 5,6 \\
Pacific sierra & Scomberomorus sierra & Scombridae & 6 \\
Flathead mullet & Mugil cephalus & Mugilidae & 5,6 \\
Sharks & Several species & & 5 \\
\hline
\end{tabular}

interviewees were the captains of the vessels since they are the most experienced fishers. The fieldwork was carried out in October 2016 and September 2017.

In the design and application of the interview, the recommendations proposed by Neis et al. (1999) and Moreno-Báez et al. (2012) were considered, including the use of clear and everyday language, maps with basic toponomy, and validation through interviews with key administrators and informants. Questions were sought to assess the experience of the interviewees, catch by species, gears, locations and seasons.

For each question, the corresponding percentage of each possible answer was estimated. Answers to questions regarding individual species were referred to with their common names as used in the region and, subsequently, they were associated with their corresponding scientific and family names (RamírezRodríguez, 2015). The questions regarding fishing gears sought to identify the type of gear, but not to include technical details about their construction and use.

The fishermen marked the fishing locations on specially prepared maps. Geographic data were based on Ramírez-Rodríguez et al. (2006) and were complemented with information from fishers. The data were linked to the geographic information system, QGIS version 7.0 (Quantum GIS, 2014), to produce thematic maps as proposed by Close \& Hall (2006). To identify fishing zones, we constructed a database that included the distance in kilometers between fishing locations and landing ports.
Following this, a hierarchical clustering analysis, using as a distance measure the Euclidean distance and as agglomeration method the method of Ward's using $\mathrm{R}$ language (R Core Team, 2015) was performed; the fishing areas were considered as a set of approximate catch sites that form a different group in the group diagram. The areas were grouped in zones to represent the spatial heterogeneity according to the results of the cluster analysis and external criteria such as depth of the sites, the target species captured and the proximity between the sites.

The definitions of the operational units (OUs) were derived from the relationship between the target species and the fishing gear. We used a presence-absence database and Ward's hierarchical grouping method (McCune et al., 2002). As recommended by Tzanatos et al. (2006), the definitions were complemented considering the information obtained from surveys on fishing gears, catch seasons and management schemes that apply in the region.

Each group was defined as an operative unit, i.e., a group of boats using a defined fishing gear to catch specific target species. Each OU was characterized considering the maximum and average catch data, the value of the catch per trip and frequency of use of the fishing zones and seasons.

The degree of activity per month of each OU was estimated as the percentage of fishers that reported to have participated in a given $\mathrm{OU}$ in a given month. Considering the seasonal trends in the seawater temperature within the region (Barjau-González et al., 2014), activity data was grouped by trimester. During 
October-December mean water temperature is around $21^{\circ} \mathrm{C}$; from January to March it is $13^{\circ} \mathrm{C}$; April to June $21^{\circ} \mathrm{C}$ and from July to September $24^{\circ} \mathrm{C}$.

Thematic maps of fishing zones used to show the overlap of the OU activities were made to describe the interaction processes between operative units.

\section{RESULTS}

About $90 \%$ of the 74 fishers interviewed belong to 12 of the 18 cooperatives that operate in the region of San Ignacio; $10 \%$ work for private businesses. The average age of the fishermen is 43 years, and $88 \%$ have more than 10 years of fishing experience in the region. These data suggest that the respondents have sufficient experience to comment on the development of fishing in the region.

The fishermen referred to the capture of at least 15 species and the use of six types of fishing gears (Table 1). According to $44 \%$ of the responders, the maura pen shell Atrina maura was the most important resource, followed by the rugose pen shell Pinna rugose 39\%, California flounder Paralichthys californicus 20\%, yellow amberjack Seriola lalandi $17 \%$, and barred sand bass Paralabrax nebulifer 16\%. Seventy percent of the fishermen considered the beach selling price as a factor indicating the importance of the resource; $27 \%$ considered the resource abundance to indicate importance. Although the response possibilities included market demand, operation costs and license availability, these factors were not found to be relevant.

From the cluster analysis between fishing gears and captured species, we identified 10 groups (Fig. 2). However, additional information from surveys allowed us to get a better definition of operative units. The trapwarrior swim crab Callinectes bellicosus and the trapMexican spiny lobster Panulirus interruptus belonged to a single group. However, each of them uses specifically designed traps according to the target species and was managed as independent units (SAGARPA, 2012); therefore, were classified as independent operative units.

The diving-scallop (pen shells) cluster includes two different target species, but both are captured using the same technique and are registered together in fishing landings records. As a consequence, they represent the same fishery, including two species (Maura pen shell and rugose pen shell).

The cluster diving-squalid callista Megapitaria squalida and diving-Pismo clam Tivela stultorum includes two independent OUs because the target species are registered and managed by different institutions: the Callista one by Comisión Nacional de
Acuacultura y Pesca-CONAPESCA (SAGARPA, 2012), and the Pismo one by Secretaría de Medio Ambiente y Recursos Naturales (SEMARNAT, 2010).

The finfish fisheries are clearly multispecific, but they were divided into two operative units according to the fishing gear type: bottom and surface nets. The former comprised as target species the California flounder, yellowtail amberjack, and shortfin weakfish Cynoscion parvipinnis. The surface net cluster included as target species the white weakfish Atractoscion nobilis, Pacific sierra Scomberomorus sierra, and flathead mullet Mugil cephalus.

From the ten groups obtained in the analysis, we distinguish 11 operative units: 7 métiers and four fisheries. 1: trap-barred sand bass, 2: trap-Mexican spiny lobster, 3: trap-warrior swim crab, 4: divingscallop (pen shells), 5: diving-squalid callista, 6: diving-Pismo clam, 7: cast netyellowleg shrimp, 8: manual collection-black ark, 9: bottom nets-sharks, 10: surface nets-fish (white weakfish, Pacific sierra and flathead mullet), and 11: bottom nets-fish (California flounder, yellowtail amberjack and shortfin weakfish).

On average, the operative units with the highest activity were trap-barred sand bass, trap-Mexican spiny lobster, diving-pen shells and bottom nets-fish (Fig. 3). The percentage of each OU activity could be related to official temporary closures and relative abundance of target species. Some units remained in operation throughout the year, and others could be active for two or three seasons; only the cast net-shrimp OU is active for one season.

The general production cycle in the San Ignacio region showed that barred sand bass $\mathrm{OU}$ is active throughout every season, representing between 30 and $37 \%$ of the total activity per season. During OctoberDecember, the trap-lobster OU exhibits a peak of activity (28\%), as well as the trap-swim crab (16\%); during this period, five other OUs are active but contribute less than $10 \%$ each to the total activity. During January-March, the lobster and the swimming crab OUs decreased activity (15 and 8\%, respectively), while the pen shell OU becomes active (36\%); during this season, the shark and Pismo clam OUs exhibit very low activity. From April to June, the activity of the pen shell and the swimming crab OUs decrease, but the bottom net fish OU is highly active, followed by the surface net fish OU; during this period, the squalid callista and the black ark OU become active. Finally, during July-September, as the activity of the pen shell OU decreases, the bottom net fish OU is maximally active (27\%), and the warrior crab, the surface net fish, and the bottom net sharks OUs increase participation (Fig. 3). 


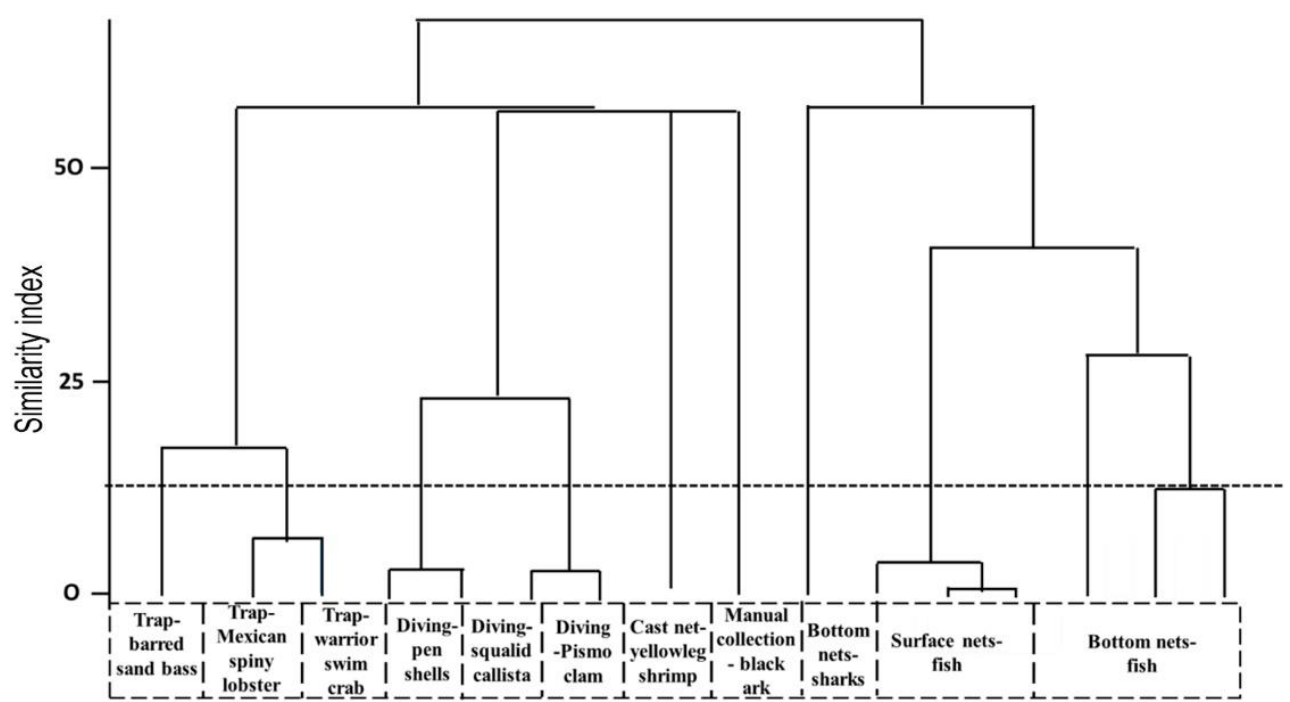

Figure 2. Operative units of the small-scale fleet in the San Ignacio region.

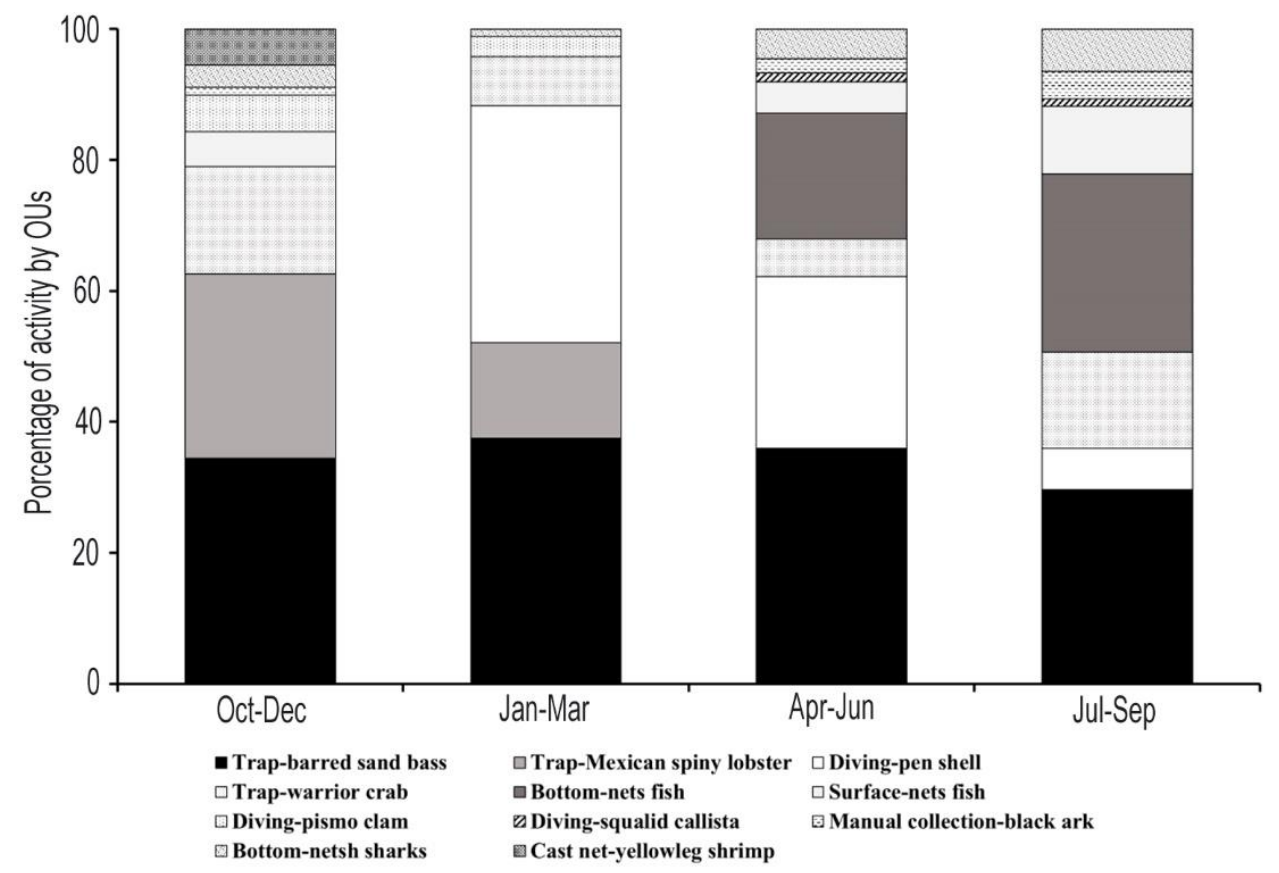

Figure 3. Percentage of activity per trimester for each operative unit in the San Ignacio region.

The alternative use of the different resources was also related to physiographic characteristics at the fishing zones, depth and the position of fishers in- or outside of the lagoon. The intention to group areas on the fishing zone was to represent the higher spatial heterogeneity of the region, taking into account the depth of the sites, the target species and the proximity between the sites.

From the cluster analysis, we found evidence of five fishing zones (Fig. 4). Zone Z1 was located inside and in the upper part of the lagoon; Z2 was located in the middle part of the lagoon; Z3 included areas near the mouth of the lagoon, Estero del Cardón, and the coastal area; Z4 and Z5 included the deeper fishing localities at the San Ignacio region (Z4 at the southern part and Z5 at the northern part of the same region (Fig. 5).

In zones, $\mathrm{Z} 1$ and $\mathrm{Z} 2,80 \%$ of the fishermen participate in the diving-pen shell OU (Fig. 6). In the coastal zones (Z4 and Z5), the OUs trap-barred sand bass and bottom-nets fish (51\%) are predominant. In 


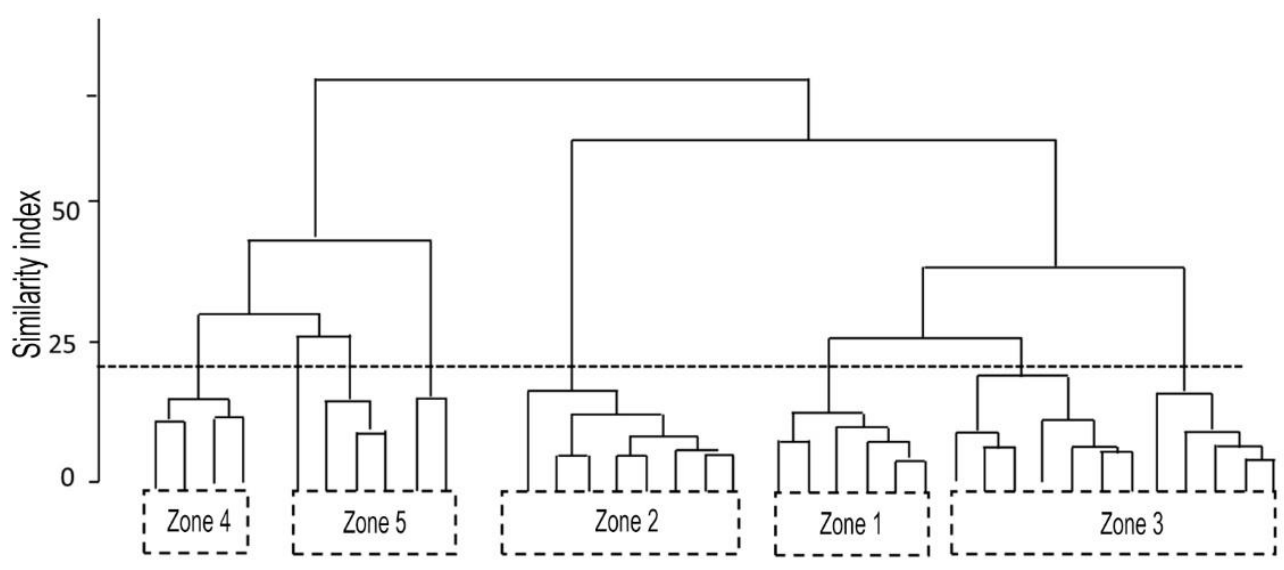

Figure 4. Fishing zones of the small-scale fleet in the San Ignacio region.

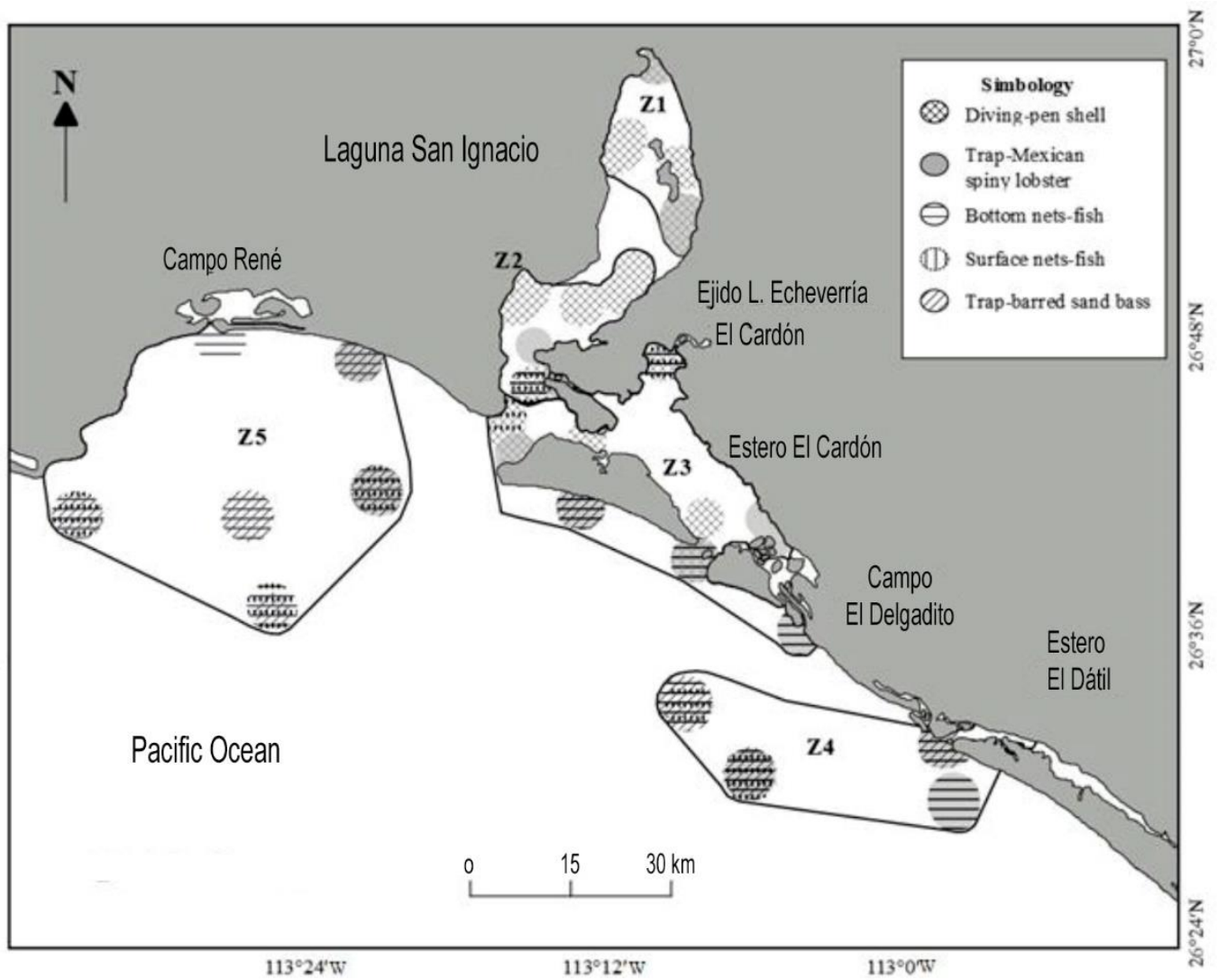

Figure 5. Fishing zones (Z1, Z2, Z3, Z4, Z5) used by the operative units diving-scallop, trap-barred sand bass, bottom netsfish, surface nets-fish, and trap-lobster.

zone $\mathrm{Z3}$, in shallow areas, the OUs diving-Pismo clam and diving-squalid callista occur, but in the deeper regions, the most OUs active are bottom nets, surface nets, and the OU trap-Mexican spiny lobster. This information allows the identification of interaction processes between the OUs in the region.

\section{DISCUSSION}

The interviews with the fishermen provided valuable information for the evaluation of fishery dynamics in the region of San Ignacio; the findings of this study are relevant to the design of sustainable, integrated, efficient and specific management in the context of 


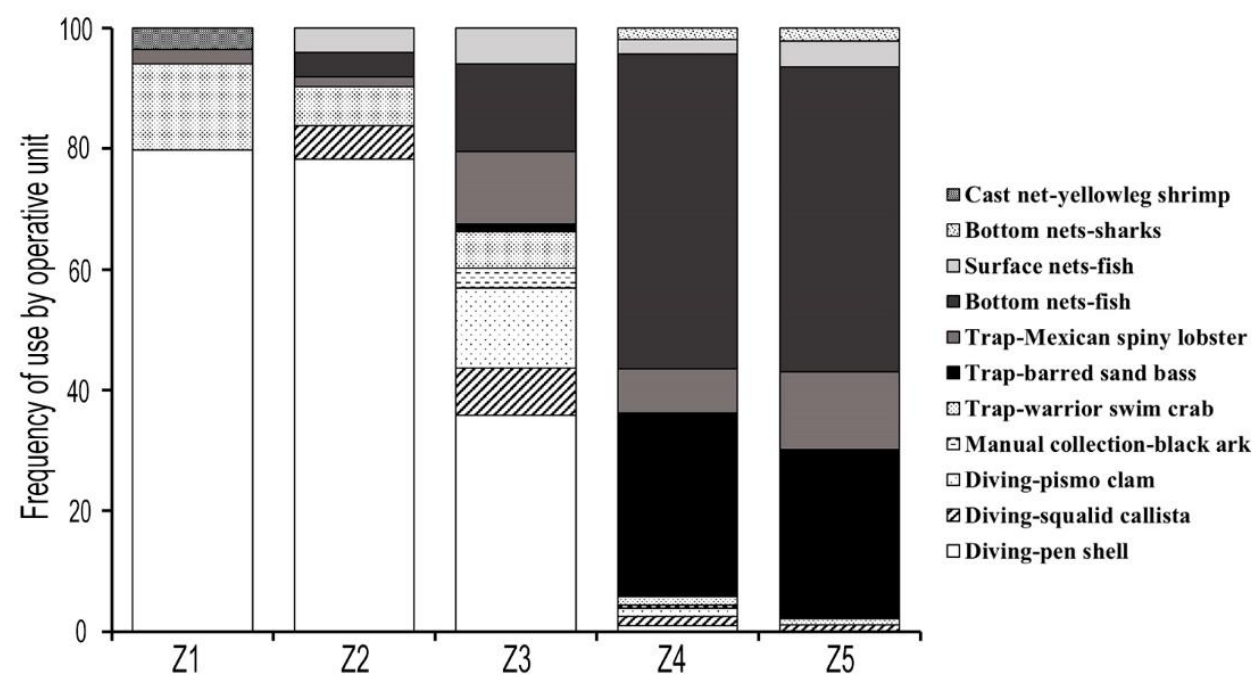

Figure 6. Frequency of use of fishing zones by operative units.

regional mixed fisheries. Professional fishers with the extensive experience provided the data and crosschecked questions related to species, catch quantities, seasons and fishing areas that facilitated the assessment of consistency in the answers. Also, the obtained information was verified through key informants that included anglers, administrators and academics.

Other studies (Rijnsdorp et al., 2000; Salas \& Gaertner, 2004; Tzanatos et al., 2006; RamírezRodríguez, 2011; Barnes-Mauthe et al., 2013) have indicated similar complexity and dynamics to the fisheries of San Ignacio attributing these to the diversity of target species, gears, fishing zones and seasons and documenting that this complexity offers the fishermen rentable, secure and comfortable alternatives. However, the possibility of working in one or another OU, i.e., fishers' adaptive capacity, being defined in some cases as generalists (Cabrera \& Defeo, 2001; Tzanatos et al., 2006; Forcada et al., 2010), depends on the fisher having the necessary license and following decisions that have been made based on the abundances, costs and distance to the base port, but the combination provides the fishermen with possible production cycles and alternatives.

In this region, as in others (Accadia \& Franquesa, 2006; Ramírez-Rodríguez \& Ojeda-Ruiz, 2012), the OUs are involved in seasonal rotation processes, determined by fishing success according to the season and the fishing zones. In San Ignacio, seasonal rotation processes are related to compliance with temporary closures of fishing for lobster and shrimp, the abundance and price of pen shells, and Pismo clam Tivela stultorum, the abundance of barred sand bass Paralabrax nebulifer (despite their low price). The availability of fish that are accessible using bottom and surface nets during summer and of warrior swim crab Callinectes bellicosus, squalid callista Megapitaria squalida, and black ark Anadara tuberculosa during short seasons.

The definition of fishing zones allows the recognition of spatial-temporal differences in the exploitation of resources and the generation of indicators that allow assessment of interaction effects between fisheries on appropriate geographic scales (Moreno-Báez et al., 2012; Ojeda-Ruiz \& RamírezRodríguez, 2014; Ojeda-Ruiz et al., 2015). The distance of the catch location from the base ports is important. For example, the OUs diving-pen shells, diving-squalid callista and trap-warrior mainly operate near the ports, but the traps for barred sand bass and the bottom and surface nets for fish can operate much further away from the ports. The fishers must have a preference for the OUs they participate in, the seasons and the costs of each one.

The interactions between the OUs are related to the fishing zones and seasons, and the management of these interactions should consider the fleet dynamics (Tzanatos et al., 2006). In some zones, the number of OUs that are simultaneously active is low, and, therefore, any subsequent interactions would be low. In contrast, the increased number of simultaneously active OUs in other zones results in higher interactions. The challenge for regional fisheries management, which strives for ecological, social and economic sustainability, is to consider the potential effects that implementing regulation on a specific OU could have on the other OUs with which it interacts. For example, the effect of approving a protected marine area on the 
different OUs that are active within that region, which, depending on the number of licenses held by fishers, might influence the fishing effort for a particular target species, e.g., finfish.

Regarding economic profits, all the OUs and fish products that are commercialized are essential for the sustainability of the fishing cooperatives and private businesses located in the region. The results of the present study, in the region of San Ignacio, indicate the necessity of regional management plans to consider the performance of each operational unit and the possible effects of their interactions on their activities and, thus, on regional fishing. In the short term, the management measures applied in regional fisheries should consider the dynamics and interaction of the operative units, for which it is necessary to define the indicators, laws and management controls related to the interaction between fisheries (Vinther et al., 2004; Hilborn, 2011; Gascuel et al., 2012). Following Salas \& Gaertner (2004), sustainability cannot be achieved with regulations based on data from natural resources alone.

From a management perspective, by recognizing operative units, it is possible to clarify which are associated with their métier characteristics, i.e., one species - one fishing gear (trap-lobster, trap-swim crab, cast net-shrimp). Whereas, for others, the rules are not so well defined since their OU characteristics are associated with the fishery level, i.e., several species several models of one type of fishing gear. In Mexico, fishers require a finfish license to use different nets or traps for fishes. Our results show that recognizing the OUs bottom nets-fishes, surface nets-fishes, and trapbarred sea bass, would allow the implementation of a particular set of rules in each case, based on fishing gear selectivity, for different groups of species (species catch composition) in time and space. However, an analysis is necessary because, on the one hand, it will improve fisheries management, but on the other, it will restrict the fishers' adaptive capacity. Recognizing the interactions between OUs facilitates understanding of the strategies used by fishers to achieve their economic and social goals (Ojeda-Ruiz \& Ramírez-Rodríguez, 2014). For the manager, it will enhance understanding of how to control total fishing effort (in time and space) and, simultaneously, promote new or reinforce current economic activities for the fishers and communities according to the region's characteristics.

\section{CONCLUSIONS}

The fishing agreements established in the region of San Ignacio, which are derived from the fishermen's spatial and temporal knowledge of the technical processes, contribute to the understanding of how the activities of the operative units develop in production cycles that support the performance of the economic units. This approach could be useful for small scale fisheries in any region and allows further discussion about the objectives of the operative units in a given region. Recommendations for management action and potential studies that contribute to the anticipation of conflicts arising from changes in the operation patterns as a result of overfishing, the environment, or management measures implemented on an operative unit without considering their effects on others.

As indicated by Salas \& Gaertner (2004) and Monroy et al. (2010), traditional management schemes overlook the behavior of the fishermen, who are an integral part of the system. Of particular interest is the study of the interactions between operative units and management possibilities, including the use of different fishing zones, the competitive behavior of the fishermen and their ability to adapt to changes in the system.

\section{ACKNOWLEDGMENTS}

The National Polytechnic Institute of Mexico (Instituto Politécnico Nacional) supported this work. FJMP thanks to the Mexican National Science Council (CONACYT). Graham Hope did the English edition.

\section{REFERENCES}

Accadia, P. \& Franquesa, R. 2006. The operational units approach for fisheries management in the Mediterranean Sea. Studies and Reviews, General Fisheries Commission for the Mediterranean 80, FAO, Rome, $36 \mathrm{pp}$.

Andersen, B.S., Ulrich, C., Eigaard, O.R. \& Christensen, A.S. 2012. Short-term choice behavior in a mixed fishery: investigating métier selection in the Danish gillnet fishery. ICES Journal of Marine Science, 69: 131-143.

Arce-Acosta, M., Ramírez-Rodríguez, M. \& De la CruzAgüero, G. 2018. Small-scale fisheries operative units in the west-central region of the Gulf of California, Mexico. Ocean \& Coastal Management, 160: 58-63.

Arreguín-Sánchez, F. \& Arcos-Huitron, E. 2011. La pesca en México: estado de la explotación y uso de los ecosistemas. Hidrobiológica, 21: 431-462.

Barjau-González E., Galván-Magaña, F., AbitiaCárdenas, L.A., Moreno-Sanchez, X.G. \& RodríguezRomero, J. 2014. Zoogeographic analysis of the fish fauna associated with soft bottoms during El Niño-La Niña (98-99) in San Ignacio Lagoon, Baja California Sur, Mexico. Journal of Biodiversity, Bioprospecting and Development, 1: 123 pp. 
Barnes-Mauthe, M., Olesona, K.L.L. \& Zafindrasilivononac, B. 2013. The total economic value of smallscale fisheries with a characterization of post-landing trends: an application in Madagascar with global relevance. Fisheries Research, 147: 175-185.

Battaglia, P., Romeo, T., Consoli, P., Scotti, G. \& Andaloro, F. 2010. Characterization of the artisanal fishery and its socio-economic aspects in the central Mediterranean Sea (Aeolian Islands, Italy). Fisheries Research, 102: 87-97.

Berkes, F., Mahon, R., McConney, P., Pollnac, R. \& Pomeroy, R. 2001. Managing small-scale fisheries: alternative directions and methods. International Development Research Centre, Ottawa.

Branch, T.A., Hilborn, R., Haynie, A.C., Fay, G., Flynn, L., Griffiths, J., Marshall, K.N., Randall, J.K., Scheuerell, J.M., Ward, E.J. \& Young, M. 2006. Fleet dynamics and fishermen behavior: lessons for fisheries managers. Canadian Journal of Fisheries and Aquatic Sciences, 63: 1647-1668.

Cabrera, J.L. \& Defeo, O. 2001. Daily bioeconomic analysis in a multispecific artisanal fishery in Yucatan, México. Aquatic Living Resources, 14: 19-28.

Castro, J., Marín, M., Pérez, N., Pierce, G.J. \& Punzón, A. 2012. Identification of métiers based on economic and biological data: the Spanish bottom otter trawl fleet operating in non-Iberian European waters. Fisheries Research, 125-126: 77-86.

Cisneros-Mata, M.A., Ramírez-Félix, E., García-Borbón, J.A., Castañeda-Fernández de Lara, V., LabastidaChe, A., Gómez-Rojo, C. \& Madrid-Vera, J. 2014. Pesca de jaiba en el litoral del Pacífico mexicano. Instituto Nacional de la Pesca, Ciudad de México, 86 pp.

Close, C.H. \& Hall, G. 2006. A GIS-based protocol for the collection and use of local knowledge in fisheries management planning. Journal of Environmental Management, 78: 341-352.

Davie, S. \& Lordan, C. 2011. Definition, dynamics and stability of métiers in the Irish otter trawl fleet. Fisheries Research, 111: 145-158.

Duarte, R., Acevedo, M. \& Alonso-Dias, M. 2009. Segmentation and fishery characteristics of the mixedspecies multi-gear Portuguese fleet. ICES Journal of Marine Science, 66: 594-606.

Espino-Barr, E. \& Cruz-Romero, M. 2006. Aspectos generales de la pesca ribereña en el Pacífico Mexicano. In: Guzmán-Amaya, P. \& Fuentes-Castellanos, D. (Eds.). Pesca, acuacultura e investigación en México. Centro de Estudios para el Desarrollo Rural Sustentable y la Soberanía Alimentaria, Cámara de Diputa- dos LIX Legislatura/Congreso de la Unión, México, pp. 37-47.

Espinoza-Romero, M.J., Cisneros-Mata, M.A., McDaniels, T. \& Torre, T. 2014. Aplicación del enfoque ecosistémico al manejo de pesquerías artesanales. Caso de estudio: Puerto Libertad, Sonora. Ciencia Pesquera, 22: 65-77.

Food and Agriculture Organization (FAO). 2005. Increasing the contribution of small-scale fisheries to poverty alleviation and food security. FAO Technical Guidelines for Responsible Fisheries, 10: 79 pp.

Fernández, J.I., Álvarez-Torres, P., Arreguín-Sánchez, F., López-Lemus, L.G., Ponce, G., Díaz-De-León, A., Arcos-Huitron, E. \& Del Monte-Luna, P. 2011. Coastal fisheries of Mexico. In: Salas, S., Chuenpagdee, R., Charles, A. \& Seijo, J.C. (Eds.). Coastal fisheries of Latin America and the Caribbean. FAO Fisheries Technical Papers, 544: 229-282.

Forcada, A., Valle, C., Sánchez-Lisazo, J.L., BayleSempere, J.T. \& Corsi, F. 2010. Structure and spatiotemporal dynamics of artisanal fisheries around a Mediterranean marine protected area. ICES Journal of Marine Science, 67: 191-203.

Funes-Rodríguez, R., Gómez-Gutiérrez, J. \& PalomaresGarcía, R. 2007. Estudios ecológicos en bahía Magdalena. Instituto Politécnico Nacional, Ciudad de México, 320 pp.

Gascuel, D., Merino, G., Doring, R., Druon, J.N., Goti, L., Guénnete, S., Macher, C., Soma, K., Travers-Trolet, M. \& Machinkson, S. 2012. Towards the implementation of an integrated ecosystem fleet-based management of European fisheries. Marine Policy, 36: 1022-1032.

González-Álvarez, J., García de la Fuente, L., GarcíaFlores, L., Fernández-Rueda, M.P. \& AlcázarÁlvarez, J.L. 2016. Identification and characterization of metiers in multi-species artisanal fisheries. A case study in northwest Spain. Natural Resources, 7: 295314.

Hilborn, R. 2011. Future directions in ecosystem-based management: a personal perspective. Fisheries Research, 108: 234-239.

International Commission for the Exploration of the Sea (ICES). 2003. Report of the study group on development of fishery-based forecast. ICES CM 2003/ACFM: 08.

International Commission for the Exploration of the Sea (ICES). 2008. Report of the working group on multispecies assessment methods (WGSAM). 6-10 October 2008, Copenhague, ICES CM 2008/ RMC: 06.

Instituto Nacional de Estadística y Geografía (INEGI). 2010. Indicadores socioeconómicos, índice y grado de 
marginación por localidad. Baja California Sur. [http:// www.beta.inegi.org.mx/app/indicadores/\#]. Reviewed: June 1, 2018.

Kempf, A., Mumford, J., Levontin, P., Leach, A., Hoff, A., Hamon, K., Bartelings, H., Vinther, M., Staebler, M. \& Poos, J.J. 2016. The MSY concept in a multiobjective fisheries environment - lessons from the North Sea. Marine Policy, 69: 146-158.

León-Carballo, G. \& Muciño-Díaz, M. 1996. La pesquería de abulón. In: Casas-Valdez, M. \& Ponce-Díaz, G. (Eds.). Estudio del potencial pesquero y acuícola de Baja California Sur. Volumen I. Centro de Investigaciones Biológicas del Noroeste S.C., Baja California Sur, pp. 15-42.

Lluch-Belda, D. 2000. Centros de actividad biológica en la costa occidental de Baja California. In: Lluch-Belda, D., Elorduy-Garay, J., Lluch-Cota, S.E. \& Ponce-Díaz, G. (Eds.). Centros de actividad biológica del Pacífico mexicano. Centro de Investigaciones Biológicas del Noroeste S.C., Baja California Sur, pp. 49-64.

Marchal, P. 2008. A comparative analysis of métiers and catch profiles for some French demersal and pelagic fleets. ICES Journal of Marine Science, 65: 674-686.

Marchal, P., De Oliveira, J.A.A., Lorance, P., Baulier, L., \& Pawlowski, L. 2013. What is the added value of including fleet dynamics processes in fisheries models? Canadian Journal of Fisheries and Aquatic Sciences, 70: 992-1010.

Massó-Rojas, J.A. \& Fajardo, L. 1996. Pesquería de almeja pismo. In: Casas-Valdez, M. \& Ponce-Díaz, G. (Eds.). Estudio del potencial pesquero y acuícola de Baja California Sur. Volumen I. Centro de Investigaciones Biológicas del Noroeste S.C., Baja California Sur, pp. 7-85.

McCune, B., Grace, J. \& Urban, D. 2002. Analysis of ecological communities. MjM Software Design, Oregon.

Monroy, C., Salas, S. \& Bello-Pineda, J. 2010. Dynamics of fishing gear and spatial allocation of fishing effort in a multispecies fleet. North American Journal of Fisheries Management, 30: 1187-1202.

Moreno-Báez, M., Orr, B.J., Cudney-Bueno, R. \& Shaw, W.E. 2010. Using fishers' local knowledge to aid management at regional scales: spatial distribution of small-scale fisheries in the northern Gulf of California, Mexico. Bulletin of Marine Science, 86: 339-353.

Moreno-Báez, M., Cudney-Bueno, R., Barron, J.O., Shaw, W.W., Pfister, T., Torre-Cosio, J., Loaiza, R. \& Rojo, M. 2012. Integrating the spatial and temporal dimensions of fishing activities for management in the northern Gulf of California, Mexico. Ocean \& Coastal Management, 55: 111-127.

Neis, B., Schneider, D.C., Felt, L., Haedrich, R.L., Fisher, J. \& Hutchins, J.A. 1999. Fisheries assessment: what can be learned from interviewing resource users? Canadian Journal of Fisheries and Aquatic Sciences, 56: 1949-1963.

Ojeda-Ruiz, M.A. \& Ramírez-Rodríguez, M. 2014. Interactions among shrimp and "catarina" clam fisheries at Magdalena Bay, Baja California Sur Mexico. Ocean \& Coastal Management, 88: 31-37.

Ojeda-Ruiz, M.A., Ramírez-Rodríguez, M. \& De la CruzAgüero, G. 2015. Mapping fishing grounds from fleet operation records and local knowledge: the Pacific calico scallop (Argopecten ventricosus) fishery in Bahia Magdalena, Mexican Pacific. Ocean \& Coastal Management, 106: 61-67.

Quantum GIS Development Team. 2014. Quantum GIS Geographic Information System. Open Source Geospatial Foundation Project. [http://qgis.osgeo.org]. Reviewed: April 30, 2018.

R Core Team. 2015. R: a language and environment for statistical computing. R Foundation for Statistical Computing. [http://www.R-project.org/]. Reviewed: April 30, 2018.

Ramírez-Rodríguez, M. 2009. Pesquerías de pequeña escala en el noroeste de México. In: Urciaga-García, J., Beltrán-Morales, L.F. \& Lluch-Belda, D. (Eds.). Recursos marinos y servicios ambientales en el desarrollo regional. Centro de Investigaciones Biológicas del Noroeste S.C., Baja California Sur, pp. 157176.

Ramírez-Rodríguez, M. 2011. Data collection on the small-scale fisheries of México. ICES Journal of Marine Science, 68, 1611-1614.

Ramírez-Rodríguez, M. 2015. Relating scientific names to common names for important fisheries species of the Mexican Pacific. Fisheries, 40: 69-71.

Ramírez-Rodríguez, M. \& Ojeda-Ruiz, M.A. 2012. Spatial management of small-scale fisheries on the west coast of Baja California Sur, Mexico. Marine Policy, 36: 108-112.

Ramírez-Rodríguez, M., López-Ferreira, C. \& HernándezHerrera, A. 2006. Atlas de localidades pesqueras en México, 2: Baja California Sur. IPN-SAGARPACONAPESCA, Baja California Sur, 124 pp.

Ramírez-Rodríguez, M., De la Cruz-Agüero, G., MarínMonroy, E.A., Ojeda-Ruiz de la Peña, M.A. \& PonceDíaz, G. 2010. Estudio sobre la caracterización socioeconómica y pesquera del área del Golfo de Ulloa, Baja California Sur. CICIMAR-IPN, Baja California Sur, 66 pp.

Rijnsdorp, A., Dol, W., Hoyer, M. \& Pastoors, M.A. 2000. Effects of fishing power and competitive interactions among vessels on the effort allocation on the trip level 
of the Dutch beam trawl fleet. ICES Journal of Marine Science, 57: 927-937.

Salas, S. \& Gaertner, D. 2004. The behavioral dynamics of fishers: management implications. Fish \& Fisheries Series, 5:153-167.

Salas, S., Chuenpagdee, R., Seijo, J.C. \& Charles, A. 2007. Challenges in the assessment and management of small-scale fisheries in Latin America and the Caribbean. Fisheries Research, 87: 5-16.

Secretaría de Agricultura, Ganadería, Desarrollo Rural, Pesca y Alimentación (SAGARPA). 2007. Norma oficial mexicana NOM-029-PESC-2006, Pesca responsable de tiburones y rayas. Especificaciones para su aprovechamiento. Diario Oficial de la Federación, 14/02/2007.

Secretaría de Agricultura, Ganadería, Desarrollo Rural, Pesca y Alimentación (SAGARPA). 2012. Acuerdo por el que se da a conocer la actualización de la Carta Nacional Pesquera. Diario Oficial de la Federación, 24/08/2012.

Secretaría de Agricultura, Ganadería, Desarrollo Rural, Pesca y Alimentación (SAGARPA). 2013. Norma oficial mexicana NOM-002-SAG/PESC-2013, Para ordenar el aprovechamiento de las especies de camarón en aguas de jurisdicción federal de los Estados Unidos Mexicanos. Diario Oficial de la Federación, 11/07/2013.

Received: 6 August 2018; Accepted: 1 October 2019
Secretaría de Agricultura, Ganadería, Desarrollo Rural, Pesca y Alimentación (SAGARPA). 2016. Norma oficial mexicana NOM-006-SAG/PESC-2016, para regular el aprovechamiento de todas las especies de langosta en las aguas de jurisdicción federal del Golfo de México y Mar Caribe, así como del Océano Pacífico incluyendo el Golfo de California. Diario Oficial de la Federación, 07/08/2016.

Secretaría de Medio Ambiente y Recursos Naturales (SEMARNAT). 2010. Norma oficial mexicana NOM059-SEMARNAT-2010. Protección ambiental- especies nativas de México de flora y fauna silvestres categorías de riesgo y especificaciones para su inclusión, exclusión o cambio- lista de especies en riesgo. Diario Oficial de la Federación, 30/12/2010.

Tzanatos, E., Somarakis, S., Tserpes, G. \& Koutsikopoulos, C. 2006. Identifying and classifying small-scale fisheries métiers in the Mediterranean: a case study in the Patraikos Gulf, Greece. Fisheries Research, 81: 158-168.

Ulrich, C., Gascuel, D., Dunn, M., Le Gallic, B. \& Dintheer, C. 2001. Estimation of technical interactions due to the competition for resources in a mixed-species fishery, and the typology of fleets and métiers in the English Channel. Aquatic Living Resources, 14: 267281.

Vinther, M., Reeves, S.A. \& Patterson, K.R. 2004. From single-species advice to mixed-species management: taking the next step. ICES Journal of Marine Science, 61: 1398-1409. 